\title{
Understanding Alcohol Abuse Among College Students: Contributing Factors And Strategies For Intervention
}

\author{
Rosemary Iconis, Queensborough Community College of the City University of New York, USA
}

\begin{abstract}
Alcohol abuse among college students has become a major public health concern. Individual, environmental, and demographic factors have each been associated with alcohol abuse in that population. In response to the enormous physical, emotional, and legal consequences that occur as a result of the abuse, colleges and universities are developing strategies for prevention and intervention.
\end{abstract}

Keywords: Alcohol Abuse; College Students; Intervention Strategies

\section{INTRODUCTION}

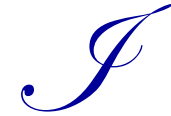

n 1993, researchers from the Harvard School of Public Health examined the drinking behavior of college students. The project, titled the College Alcohol Study (CAS), consisted of a series of nationwide surveys of approximately 140 institutions of higher education across the United States with 17,592 responses. The CAS found that $44 \%$ of students reported binge drinking (defined as five or more drinks in one sitting for men, four for women) and almost half of those who were frequent binge drinkers (at least once in two weeks) experienced five or more drinking-related problems. Frequent binge drinkers were 10 times more likely than non-binge drinkers to report trouble with campus police, damage to property, injuries, and unplanned, unprotected sex (Wechsler et al., 1994; Wechsler et al., 1995). In the years following the CAS, the rate of binge drinking among college students has hardly changed.

According to the National Survey on Drug Use and Health (HHS), Substance Abuse and Mental Health Services Administration (SAMHSA), and Office of Applied Studies (US Department of Health and Human Services, 2007), $45.5 \%$ of college students engage in binge drinking and $19 \%$ engage in frequent binge drinking. It is estimated that $31 \%$ of the 8 million college students in the U.S. (ages 18 to 24) meet the Diagnostic and Statistical Manual of Mental Disorders (American Psychiatric Association, 2000) criteria for alcohol abuse and another six to eleven percent meet the criteria for alcohol dependence (Knight et al., 2002).

\section{FACTORS ASSOCIATED WITH ALCOHOL ABUSE IN COLLEGE} misuse.

Individual, environmental, and demographic factors are associated with an increased risk of alcohol use and

Among college students, individual factors, such as a family history of alcoholism, cognition (drinking motives, perceived norms), and participation in athletics, are associated with alcohol use (Baer, 2002; Bartholow et al., 2003). Environmental factors that influence alcohol use among college students include type of residence, college size, and availability of alcohol.

Jones (2007) and Braitman et al. (2009) found that, among drinkers, adult children of alcoholics (ACOAs) did not drink more frequently or more heavily than non-ACOAs, but began drinking almost a year earlier than nonACOAs. 
Many college students consider heavy drinking to be a natural part of the college experience. The perception that heavy drinking is an integral part of the college experience has been found to be a strong predictor of heavy alcohol use among incoming freshman (Sher \& Rutledge, 2007). Bockeloo, Novik, \& Bush (2011) found that the phenomenon of drinking to get drunk (DTGD) - characterized by the premeditated, intentional consumption of alcohol with the intention to reach a state of intoxication - was common in their study of incoming freshman. Over three-fourths of the freshman in residence halls in a large public university drink to get drunk.

Reasons why students consume alcohol include enhancing their mood and helping them to cope with stress, but one of the main motivating factors for alcohol use is to fit in with their peers. While alcohol abuse is a concern for college students in general, it is a particular concern for college athletes. Hildebrand, Johnson, and Bogle (2001) found a $19 \%$ increase in binge drinkers among college students compared to non-athletes. Excessive time demands for college athletes, psychological pressures to live up to coaches, fans, and family expectations, and feelings of stress around injuries may all contribute to the athlete's tendency to turn to alcohol (Martens et al., 2006).

The college environment, including the availability of alcohol and the type of institution, will factor into alcohol use and abuse on a college campus. Schools known as "party schools" have reputations as places where students can binge drink with few consequences. Alcohol consumption during 21 st birthday celebrations (Smith et al., 2006; Hembroff et al., 2007) and pre-gaming (drinking before entering a stadium during sporting events) (Glassman et al., 2010) have been associated with excessive alcohol consumption.

At the University of Virginia, an extremely dangerous drinking event called the "Fourth-Year Fifth" involves college seniors attempting to consume a fifth of liquor on the day of the last home football game. The practice began about 25 years ago and remains a part of university tradition (Foster, 2010).

In terms of demographic characteristics, college men have been found to drink more than females, tend to binge drink more than females, and report more alcohol-related problems than females (Humara \& Sherman, 2004).

In terms of ethnicity, O'Malley and Johnston (2002) report that data from four national surveys of college students consistently show Caucasian students reporting the highest prevalence of heavy drinking followed by Hispanic and black students, respectively.

Heavy drinking among college students tends to increase as the students approach legal drinking age and levels off thereafter (Wechsler et al., 2002).

\section{COSTS OF ALCOHOL USE IN THE COLLEGE POPULATION}

The American Psychiatric Association identifies the negative effects of alcohol abuse on college and university campuses as a major public health problem and the number one problem on college campuses (HHS, 2006). Each year, almost 600,000 college students are unintentionally injured while drinking. An estimated 1,700 college students between the ages of 18 and 24 die each year from their alcohol-related unintentional injuries. Excessive drinking not only has negative consequences for the drinking students, but places other students at risk as well. Approximately 669,000 college students are assaulted each year by a college student who had been drinking.

Negative effects of alcohol abuse by college students include, but are not limited to:

- $\quad$ Sexual assault (being assaulted or committing an assault)

- $\quad$ Sexually transmitted infections and unintended pregnancies

- $\quad$ Vandalism, or property damage, and other police involvement

- $\quad$ Mental health problems

- $\quad$ Academic problems (Hingston et al., 2005; Saltz, 2004/2005; Zeigler et al., 2005).

Female college students are less likely to miss a class, get in trouble with the law, or overdose due to alcohol than male college students (Locke \& Newcomb, 2001). 


\section{IMPLICATIONS FOR PREVENTION AND INTERVENTION}

Full-time college students consume more alcohol than those not enrolled in college full-time (O'Malley \& Johnson, 2002) and have more frequent heavy drinking episodes than their non-college attending peers (NIAAA, 2002). Segrist and Pettibone (2009), in their examination of college students' perceptions of "heavy" and "problematic" drinking, found that participants' perceptions of the number of drinks constituting heavy drinking for a 21-year-old male were significantly higher than the current five drink standard for binge drinking.

In spite of consuming an equal number of drinks, a person drinking alone was more likely to be perceived by the participants as having a drinking problem compared to a person drinking with others. The college students perceived an individual's drinking as less problematic if the drinking is done in a social context; i.e., with friends. Health educators and college counselors, who are committed to reducing alcohol abuse among college students, face the challenge of convincing them that five drinks (for males) is heavy drinking and is associated with significant negative consequences.

Lewis and Myers (2010) examine wellness factors as predictors of alcohol use among undergraduates. Based on the results, college students who tend to consume more alcohol may harbor unrealistic beliefs regarding the accomplishment of their goals. Heavier drinking college students tend to place enormous expectations on themselves and are often frustrated when these expectations are not accomplished (Myers \& Sweeney, 2004). As numerous studies have found, the sense of invincibility experienced by young adults contributes to their drinking behaviors (NIH, HHS, 2006). Likewise, Lewis \& Myers' (2010) results suggest that some college students may mitigate feelings of imperfection by turning to alcohol. The findings of these studies have direct implications for health educators and college counselors. Counselors may wish to explore the faulty cognitive mechanisms and the use of alcohol consumption to mitigate the internal strife. They may utilize cognitive-behavioral and analytic methods to promote a more realistic outlook on life (Sweeney, 2010; Lewis \& Myers, 2010).

There have been many approaches established to alleviate alcohol-related problems among college students, including restrictions from alcohol social norm campaigns, peer mentoring and educational programs (Mastroleo et al., 2008; Larimer et al., 2007).

The National Institute on Alcohol Abuse and Alcoholism (2002) reviewed existing alcohol intervention programs on college campuses. The NIAAA then assigned each program to one of three tiers based on students' perceptions of effectiveness and on empirical data related to prevalence of alcohol-related problems among students. The first tier represented programs that had the best documented success rate when it came to reducing alcoholrelated problems and consumption on college campuses. These programs focused on cognitive-behavioral skills with norms clarification and motivational enhancement; brief motivational enhancement interventions; and programs that challenged alcohol expectancies. The NIAAA found that tier-2 programs, which focused on rules and sanctions and tier-3 programs, which focused on policy and education, were both less effective.

Though substantial progress has been made with respect to research on alcohol consumption among college students and the prevention of alcohol-related problems within that population, problematic drinking on college campuses remains a significant concern. Saltz (2011) identifies several questions which remain:

1. What is the optimum combination of environmental strategies that will have the greatest impact within the resources available to a college or university?

2. What is the most efficient way to implement community level strategies?

3. What will it take for colleges and universities to adopt the useful interventions?

\section{AUTHOR INFORMATION}

Dr. Rosemary Iconis is currently an Associate Professor at Queensborough Community College of the City University of New York. She is an award-winning lecturer whose papers have been presented both nationally and internationally. Accomplished as a writer and researcher, Dr. Iconis has published extensively for newspapers and magazines on topics related to the health of both children and adults. E-mail: ricon17@ optonline.net 


\section{REFERENCES}

1. American Psychiatric Association. (2000). Diagnostic and statistical manual of mental disorders (4th edition) Washington DC.

2. Baer, J. S. (2002). Student factors: Understanding individual variation in college drinking. Journal of Studies on Alcohol, Suppl. 14, 40-53.

3. Bartholow, B. D., Sher, K. J., \& Krull, J. L. (2003). Changes in heavy drinking over the third decade of life as a function of collegiate fraternity and sorority involvement: A prospective, multilevel analysis. Health Psycholog, 22(6), 616-626.

4. Boekeloo, B. O., Novik, M. G., \& Bush, E. N. (2011). Drinking to get drunk among incoming freshman college students. American Journal of Health Education, 42(2), 88-95.

5. Boekeloo, B. O., Novik, M. G., Bush, E. N., \& O’Grady, K. E. (2009). Impact of the "peers as family" dormitory wing-based intervention on college student alcohol use and its secondhand effects. Journal of Drug Education, 39(4), 339-59.

6. Braitman, A. L., Kelley, M. L., Ladage, J., Schroeder, V., Gumienny, L. A., Morrow, J. A., \& Klostermann, K. (2009). Alcohol and drug use among college student adult...(ACOAs). Journal of Alcohol and Drug Education, 53(1), 69-88.

7. Foster, H. A. (2010). $4^{\text {th }}$ year $5^{\text {th }}$ assessment (Unpublished Research). University of Virginia.

8. Glassman, T. J., Dodd, V. J., Sheu, J., Rienzo, B. A., \& Wagenaar, A.C. (2010). Extreme ritualistic alcohol consumption among college students on game day. Journal of American College Health, 58, 413-423.

9. Hembroff, L., Atkin, C., Martell, D., McCue, C., \&Greenamyer, J. (2007). Evaluation results of a $21^{\text {st }}$ birthday card program targeting high-risk drinking. Journal of American College Health, 56(3), 325-332.

10. Hildebrand, K. M., Johnson, D. J., \& Bogle, K. (2001). Comparison of patterns of alcohol use between high school and college athletes and non-athletes, College Student Journal, 35, 358-365.

11. Hingston, R., Heeren, T., Winter, M., \&Wechsler, H. (2005). Magnitude of alcohol-related mortality and morbidity among U.S. college students ages 18-24: Changes from 1998 to 2001. Annual Review of Public Health, 26, 259-279.

12. Humara, M. J., \& Sherman, M. F. (2004). Situational determinants of alcohol abuse among Caucasian and African-American college students. Addictive Behaviors, 24(1), 135-158.

13. Jones, A. L., Perera-Doltz, D. M., Salyers, K. M., Laux, J. M., \& Cochrane, W. S. (2007). Testing hypothesized differences between adult children of alcoholics (ACOAs) and non-ACOAs in a college student sample. Journal of College Counseling, 10(1), 19-26.

14. Knight, J. R., Wechsler, H., Kuo, M., Siebring, M., Weitzman, E. R, \& Schuckit, M. A. (2002). Alcohol abuse and dependence among U.S. college students. Journal of Studies on Alcohol, 63, 263-270.

15. Larimer, M. E., \& Cronce, J. M. (2007). Identification, prevention, and treatment revisited: Individualfocused college drinking prevention strategies 1999-2006. Addictive Behaviors, 32, 2439-2468.

16. Lewis, T., \& Myers, J. E. (2010). Wellness factors as predictors of alcohol use among undergraduates: Implications for prevention and intervention. Journal of College Counseling, 13(2), 111+.

17. Locke, T. F., \& Newcomb, M. D. (2001). Alcohol problems and dysphoria: A longitudinal examination of gender differences from late adolescence to adulthood. Psychology of Addictive Behaviors, 15(3), 227-236.

18. Martens, M., O'Connor, K., \& Beck, N. (2006). A systematic review of college student-athlete drinking: Prevalence rates, sport-related factors, and interventions. Journal of Substance Abuse Treatment, 31(3), 307-309.

19. Mastroleo, N. R., Mallett, K. A., \& Turrisi, R. (2008). The process of delivering peer-based alcohol intervention programs in college settings. Journal of College Student Development, 49(3), 255-259.

20. Myers, J. E., \& Sweeney, T. J. (2004). The indivisible self: An evidence-based model of wellness. Journal of Individual Psychology, 60, 234-244.

21. National Institute on Alcohol Abuse \& Alcoholism (2002). A call to action: Changing the culture of drinking at U.S. colleges. NIH Pub. No. 02-5010. Bethesda, MD: NIAAA.

22. O'Malley, P. M., \& Johnston, L. D. (2002). Epidemiology of alcohol and other drug use among American college students. Journal of Studies on Alcohol, Suppl 114, 23-39.

23. Saltz, R. (2004/2005). Preventing alcohol-related problems on college campuses - Summary of the final report of the N IAAA task force on college drinking. Alcohol Research and Health, 28, 249-252. 
24. Saltz, R. F. (2011). Environmental approaches to prevention and college settings. Alcohol Research and Health, 34(2), 204+.

25. Segrist, D. J., \& Pettibone, J. C. (2009). Where's the bar? Perceptions of heavy and problem drinking among college students. Journal of Alcohol and Drug Education, 53(1).

26. Sher, K. J., \& Rutledge, P. C. (2007). Heavy drinking across the transition to college: Predicting first semester heavy drinking from precollege variables. Addict Behavior, 32, 819-35.

27. Smith, B., Bogle, K., Talbot, L., Gant, R., \& Castillo, A. H. (2006). A randomized study of four cards designed to prevent problems during college students' 21 st birthday celebrations. Journal of Studies on Alcohol, 67, 607-615.

28. Sullivan, M., \& Risler, A. (2002) Understanding college alcohol abuse and academic performance: Selecting appropriate intervention strategies. Journal of College Counseling, 5(2) 114+.

29. Sweeney, T. J. (2010). Adlerian counseling and psychotherapy (5th ed.) New York, NY: Rouledge.

30. U.S. Department of Health and Human Services, National Institutes of Health, National Institute on Alcohol Abuse and Alcoholism (2006, April). Young adult drinking (Alcohol Alert No. 68). Retrieved from http://pubs.niaaa.nih.gov/publications/aa68/aa68.htm

31. U.S. Department of Health and Human Services, Substance Abuse and Mental Health Services Administration, Office of Applied Studies (2007). Results from the 2006 National Survey on Drug Use and Health: National findings (NSDUH Series No. H-32, HHS Publication No. SMA 07-4293). Retrieved from http://www.oas.samhsa.gov/nsduh/2k6nsduh/2k6results.pdf

32. Wechsler, H., Davenport, G., Dowdall, B., Moeykens, \& Castillo, S. (1994). Health and behavioral consequences of binge drinking in college. A national survey of students at 140 campuses. Journal of the American Medical Association, 272(21), 1672-7.

33. Wechsler, H., Lee, J. E., Nelson, T. F., \& Kuo, M. (2002). Underage college students' drinking behavior, access to alcohol, and the influence of deterrence policies. Findings from the Harvard School of Public Health College Alcohol Study. Journal of American College Health, 50(5), 226-236.

34. Wechsler, H., Moeykens, A., Davenport, S., Castillo, S., \& Hansen, J. (1995). The adverse impact of heavy episodic drinking on other college students. Journal of Studies on Alcohol, 56(6), 628-34.

35. Zeigler, D. W., Wang, C. C., Yoast, R. A., Dickinson, B. D., McCaffree, M. A., Robinowitz, C. B., \& Sterling, M. D. (2005). The neurocognitive effects of alcohol on adolescents and college students. Preventative Medicine, 40, 23-32. 
NOTES 